\title{
The Attitude of Young Romanian People on Cooperative Entrepreneurship
}

\author{
Alina-Elena Iosif ${ }^{1}$ and Caroline Hussler ${ }^{2}$ \\ 1) The Bucharest University of Economic Studies, Bucharest, Romania. \\ ${ }^{2}$ Lyon University, IAE Lyon, Magellan, France. \\ E-mail: alina.balalia@com.ase.ro; E-mail: caroline.hussler@univ-lyon3.fr
}

\begin{abstract}
Please cite this paper as:
Iosif, A.E. and Hussler, C., 2021. The Attitude of Young Romanian People on Cooperative Entrepreneurship. In: R. Pamfilie, V. Dinu, L. Tăchiciu, D. Pleșea, C. Vasiliu eds. 2021. 7th BASIQ International Conference on New Trends in Sustainable Business and Consumption. Foggia, Italy, 3-5 June 2021. Bucharest: ASE, pp. 897-904 DOI: 10.24818/BASIQ/2021/07/112
\end{abstract}

\begin{abstract}
Our paper is approaching the subject of cooperative entrepreneurship as a particular form of social entrepreneurship focused on the cooperative status of a business. The subject of cooperative entrepreneurship has still a little coverage in the scientific literature, while it is becoming more and more visible in practice. The main aim of our paper is to provide an overview of the attitude of young people on cooperative entrepreneurship in a post-communist country, namely Romania. The corresponding objectives of the paper are connected to the cognitive, affective and conative components of a common attitude model. Methodologically, we have applied a questionnaire and we have registered 95 responses. The results of our paper indicate that even though the young Romanian people have not so solid knowledge about cooperatives, they are slightly positively oriented towards the possibility of creating a cooperative as long as they are supported by a community where people are sharing similar interests and they may dispose of dedicated spaces/incubators. Based on the comfort feelings that young Romanian people experience in relation to cooperative entrepreneurship, policymakers, academia, and cooperative representatives could react and develop the necessary tools to encourage the increasing social spirit manifested by the young generation.
\end{abstract}

\section{Keywords}

Cooperative entrepreneurship, cooperative, attitude, Romania

DOI: $10.24818 / B A S I Q / 2021 / 07 / 112$

\section{Introduction}

Entrepreneurship is a highly approached topic both in literature and practice, while research on the topic of social entrepreneurship is starting to gain more popularity both among practitioners and academia. Social economy is the third economic sector that was developed as a solution for the economic and social problems that were without solving from the side of the public and private sectors. As an exponential player of the social economy, cooperatives had developed themselves in situations where the market was inefficient to serve the demand, and where the classic enterprises were not attracted to develop their activity. Even though the cooperative subject was not so attractive in the last three decades, we are encouraged to intensify our studies as the subject is receiving increasing attention from the part of business and organizational scholars (Barin Cruz, et al., 2017). Distinct from the social economy, the concept of social entrepreneurship implies the use of entrepreneurial principles for solving social problems. When talking about cooperative entrepreneurship, as part of social entrepreneurship, the research is still at its beginnings (Bastida, et al., 2020) and various directions of research could be adopted. Our paper is contributing to the literature by studying the young people's attitude on cooperative entrepreneurship. The way this article seeks to shed light on this subject is by analysing the case of a post-communist country, namely Romania. In the communist period, the 
cooperatives were considered public enterprises with management regulations established by public authorities (Petrescu, 2011), and individuals were constrained to be part of a cooperative. Nowadays, young Romanian people are manifesting a social oriented perspective (Iosif, et al., 2020; Roman and Paraschiv, 2020) making cooperative entrepreneurship an attractive choice for their careers. Another encouraging study (Țigu, et al., 2014) reveals that Romanian social entrepreneurs are motivated to adopt this position as they feel their mission is to bring changes to this world.

The main aim of the paper is to provide an overview of the attitude of young Romanian people regarding cooperative entrepreneurship, by answering the following research questions:

- What young Romanian people know about cooperatives, both in conceptual and practical terms? Conceptual direction refers to elements characterizing cooperative, and practical aspects are connected to cooperative businesses acting on the market.

- How young Romanian people feel about cooperative entrepreneurship? How challenging they find being a cooperative entrepreneur?

- What is the intention of young Romanian people in relation to cooperative entrepreneurship? Would they assume the entrepreneur position or they would like to play a more passive role in relation to a cooperative?

In the vision of answering these research questions, the paper is structured as follows: a short review of the literature regarding the attitude model, followed by aspects regarding methodology, and a section dedicated to the descriptive analysis of the collected data and its interpretation. The paper ends with a conclusion section where the main results, practical implications and limits of research are pointed out.

\section{Review of the scientific literature}

The paper is capturing the vision of young Romanian people on cooperative entrepreneurship and is answering the research questions by using a classical attitude model. After reviewing multiple definitions and models, Jain (2014) has identified the most common aspects that characterize an attitude model, concluding that it consists of three components:

- Cognitive component that is related to belief/evaluation;

- Affective component that is addressing feelings/ emotions;

- Behavioral component that is connected to response/action.

Chhabra (2021) is having a similar vision to Jain (2014), by invoking the evaluation of the consumer's attitude through the knowledge and cognitive component, the feeling and affect component, and behavioral and conative component. Further on, the connections between the research questions and the components of the attitude model are revealed.

The knowledge and cognitive component is providing information about the notoriety of the subject/ product/ mark from the consumer perspective. In our particular case, through the cognitive element we are capturing what young Romanian people know/ what is their level of knowledge about our research subject, namely cooperative and cooperative entrepreneurs.

Through the feeling and affect component, the emotional approach of the customers in relation to the subject is revealed. In the perspective of our paper, we are studying how the young Romanian people feel about cooperative entrepreneurship. When analysing the affective stage, we are capturing the feelings of the respondents towards cooperative entrepreneurship through the lens of the support young people think they need for cooperative entrepreneurship versus classic entrepreneurship.

The behavioral and conative component regards the performing action plan that is responsible for making the step from the desire to action (Roman and Paraschiv, 2020). In the vision of our research, we are seeing the conviction of the respondents in connection to cooperative entrepreneurship, by asking their preference for a particular status within the cooperative.

\section{Research methodology}

The purpose of our study is to investigate cooperative entrepreneurship through the components of the attitude model, by capturing the vision of young Romanian persons on the subject. Methodologically, 
the study is adopting a quantitative approach where the data were collected through a questionnaire applied among young Romanian people in the period of April - May 2020. The current paper is tackling nine questions out of the 18 questions of a more complex research carried on cooperative entrepreneurship among young Romanian people. In the next section of our paper, we are going to present the results of the questions that are connected to the classic attitude model and responding to our current research questions. The discussed questions are distributed as follows: five questions are regarding the knowledge of the respondents in relation to the cooperative entrepreneurship, responding to the cognitive stage; one question is capturing the feeling towards cooperative entrepreneurship through the vision on the needed support, corresponding to the affective stage; one question is connected to the respondents view on acting towards the cooperative entrepreneurship, related to conative stage; and two identification questions.

The study includes 95 responses from the young Romanian people, aged between 18-26 years old, $72 \%$ of the respondents declaring that they are females with superior studies. Moreover, $81 \%$ of the respondents have mentioned living in the urban environment.

\section{Results and discussion}

Cognitive element in relation to cooperative entrepreneurship

In the perspective of the cognitive element, we are checking the notoriety of the cooperative and cooperative entrepreneurship among young Romanian people, by assessing their level of knowledge on these subjects.

When asked to name at least a cooperative acting either nationally or internationally, $63 \%$ out of the total respondents have successfully nominalized at least one. More than half of the respondents have nominalized FruFru, a Romanian cooperative acting in the food industry, as a cooperative.

Another result of our study shows that the predominant sector associated with cooperative entrepreneurship is agriculture. $76 \%$ of the respondents have named agriculture as being the most dominant sector when talking about cooperatives, followed at a considerable distance by trade. Banking and energetic sectors were also mentioned, but in a very low proportion.

Each of the seven principles of cooperatives, as defined by the International Cooperative Alliance (ICA, n.d.), were included as items within the question that is checking the level of agreement of the respondents in connection to the cooperative status (Table no. 1). The principles associated with the functioning of a cooperative were evaluated by the respondents, by applying a Likert scale from 1 (strongly disagree) to 7 (strongly agree).

It can be seen from table 1 that the element referring to "open and voluntary membership" is "partially agreed" by the respondents as being a functioning principle of a cooperative, being the less popular principle of all (median 5). The highest percentages of "moderately agreement" per functioning principle of a cooperative were registered by the "democratic member control", and the "autonomy and independence". The "members' economic participation", "education, training and information", "cooperation among cooperatives", and "the concern for community" are the most convincing functioning principles of a cooperative into the respondents' view, registering the highest percentages for "strongly agreement" option per item. Concluding, the "open and voluntary membership" is the principle that has the lowest connection to cooperatives into the respondents' view (median 5), while the "concern for community" is strongly associated (median 7) to the way cooperatives are functioning. 
Table no. 1. The respondents' perspective on the principles that characterize the functioning of

\begin{tabular}{|c|c|c|c|c|c|c|c|c|}
\hline Principles & $\begin{array}{l}1 \\
\text { Strongly } \\
\text { disagree }\end{array}$ & 2 & 3 & 4 & 5 & 6 & $\begin{array}{l}7 \\
\text { Strongly } \\
\text { agree }\end{array}$ & Median \\
\hline $\begin{array}{l}\text { Open and } \\
\text { Voluntary } \\
\text { Membership } \\
\end{array}$ & $2.11 \%$ & $2.11 \%$ & $5.26 \%$ & $16.84 \%$ & $33.68 \%$ & $\begin{array}{l}16.84 \\
\% \\
\end{array}$ & $23.16 \%$ & 5 \\
\hline $\begin{array}{l}\text { Democratic } \\
\text { Member } \\
\text { Control }\end{array}$ & $2.1 \%$ & $0 \%$ & $2.1 \%$ & $13.7 \%$ & $27.4 \%$ & $\begin{array}{l}35.8 \\
\%\end{array}$ & $18.9 \%$ & 6 \\
\hline $\begin{array}{l}\text { Members' } \\
\text { Economic } \\
\text { Participation }\end{array}$ & $1.1 \%$ & $0 \%$ & $2.1 \%$ & $2.1 \%$ & $20 \%$ & $31.6 \%$ & $43.2 \%$ & 6 \\
\hline $\begin{array}{l}\text { Autonomy and } \\
\text { Independence }\end{array}$ & $1.1 \%$ & $2.1 \%$ & $8.4 \%$ & $13.7 \%$ & $21.1 \%$ & $\begin{array}{l}27.4 \\
\% \\
\end{array}$ & $26.3 \%$ & 6 \\
\hline $\begin{array}{l}\text { Education, } \\
\text { Training, and } \\
\text { Information }\end{array}$ & $1.1 \%$ & $0 \%$ & $2.1 \%$ & $5.3 \%$ & $15.8 \%$ & $27.4 \%$ & $48.4 \%$ & 6 \\
\hline $\begin{array}{l}\text { Cooperation } \\
\text { Among } \\
\text { Cooperatives }\end{array}$ & $1.1 \%$ & $1.1 \%$ & $3.2 \%$ & $10.5 \%$ & $16.8 \%$ & $24.2 \%$ & $43.2 \%$ & 6 \\
\hline $\begin{array}{l}\text { Concern for } \\
\text { Community }\end{array}$ & $1.1 \%$ & $0 \%$ & $2.1 \%$ & $3.2 \%$ & $15.8 \%$ & $27.4 \%$ & $50.5 \%$ & 7 \\
\hline
\end{tabular}

Further on, a view on the connection that respondents are making between several business brands and the cooperative status (Figure no. 1) is provided. The referred businesses within this question are all cooperatives. By addressing this question, we are checking the level of knowledge of the young Romanian people regarding certain businesses that are functioning as cooperative.

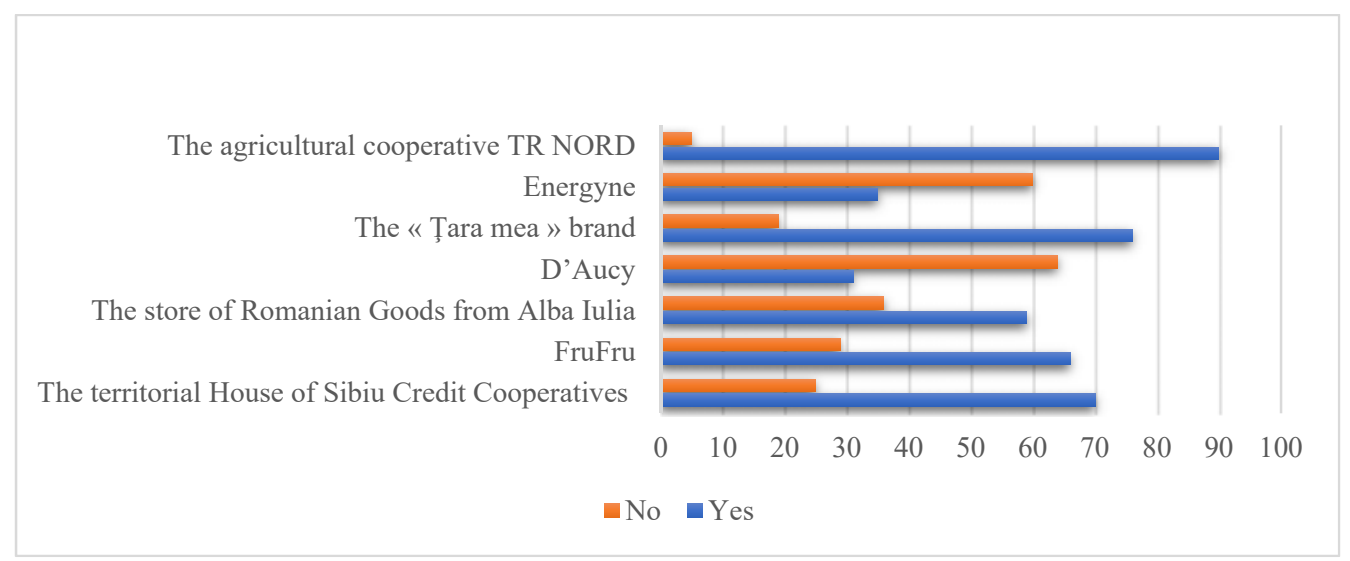

Figure no.1. The respondents' perspective on the cooperative status of the invoked businesses

In most of the cases, there are more respondents confirming that the businesses are cooperatives than the ones rejecting this hypothesis. There are also two cases that are getting out of the pattern, namely D'Aucy and Energyne, where there are more respondents that are not considering them as cooperative brands. This situation may enforce the idea that respondents are guided by the names of the brands, associating contemporary brand names with classic enterprises and less with cooperatives that "are from the past" (Iosif, et al., 2020). The cooperatives that registered the highest recognition are the cooperatives that have included in their name the "cooperative" term, such as Cooperativa Agricolă TR Nord and Casa teritorială a cooperativelor de credit Sibiu, or the cooperatives that have managed to be more visible on the market through their products, such as FruFru and the "Țara mea" brand. 
The spread of knowledge among young people regarding cooperative businesses is a double responsibility, on one way the young Romanian people as consumers could be more informed, and on the other hand the cooperatives themselves as providers of products/services could invest more in their brands' awareness. Young people are invoking the need for a higher visibility on the market of the cooperatives and they are claiming the presence of cooperatives on social media (Iosif et al., 2020) in order to reach them fast.

Further on, we are accelerating on the component of knowledge regarding cooperatives among the young Romanian public by capturing their view on several statements (Table no. 2).

The highest proportion (32.6\%) of the respondents are "partially agreeing" that the cooperative is an enterprise as any other, and the median of 4 is indicating a neutral position of the respondents towards this statement. In the case of the second item, $38 \%$ of respondents are "partially agreeing" that the cooperative is differentiating from the classic enterprise by its way of operating, and the median of 6 is showing a "moderate agreement" of the respondents towards this statement.

Table no. 2. The respondents' perspective regarding cooperatives

\begin{tabular}{|c|c|c|c|c|c|c|c|c|}
\hline Items & \begin{tabular}{|l|} 
1-Strongly \\
disagree
\end{tabular} & 2 & 3 & 4 & 5 & 6 & $\begin{array}{l}\text { 7- Strongly } \\
\text { agree }\end{array}$ & Median \\
\hline $\begin{array}{l}\text { It is an enterprise as any } \\
\text { other. }\end{array}$ & 8.42 & 8.42 & 17.89 & 22.11 & 32.63 & 9.47 & 1.05 & 4 \\
\hline $\begin{array}{l}\text { It differs from the classical } \\
\text { enterprise by the way it } \\
\text { operates. }\end{array}$ & 0.00 & 0.00 & 1.05 & 8.42 & 37.89 & 33.68 & 18.95 & 6 \\
\hline $\begin{array}{l}\text { It differs from the classical } \\
\text { enterprise by its legal } \\
\text { form. }\end{array}$ & 3.16 & 1.05 & 1.05 & 25.26 & 26.32 & 26.32 & 16.84 & 5 \\
\hline $\begin{array}{l}\text { It differs from the classical } \\
\text { enterprise by the initiating } \\
\text { procedure. }\end{array}$ & 0.00 & 0.00 & 3.16 & 16.84 & 27.37 & 28.42 & 24.21 & 6 \\
\hline $\begin{array}{l}\text { It differs from the classical } \\
\text { enterprise by its daily } \\
\text { management system. }\end{array}$ & 1.05 & 0.00 & 0.00 & 20.00 & 26.32 & 30.53 & 22.11 & 6 \\
\hline $\begin{array}{l}\text { It has a more complex } \\
\text { management system } \\
\text { compared to a classic } \\
\text { enterprise. }\end{array}$ & 2.11 & 2.11 & 3.16 & 29.47 & 14.74 & 25.26 & 23.16 & 5 \\
\hline
\end{tabular}

Moreover, the respondents are "moderately agreeing" (median of 6) that the cooperative is differentiating from the classic enterprise by both its "initiating procedure" and its "daily management system". Overall, the respondents are more convinced on the facts that, compared to a classic enterprise, the cooperative differs by its way of operating, its initiating procedure and its daily management system. These aspects are partially true, indicating a good knowledge among respondents, but also a potential reluctance towards the unknown.

\section{Affective element in relation to cooperative entrepreneurship}

An image on the respondents' feelings when picturing themselves putting into practice a cooperative is provided in order to highlight the affective element of the attitude model. Concretely, we are checking their perspective on the support they need for being a cooperative entrepreneur. Depending on the number of support initiatives that respondents are nominalizing as being relevant for them to enter into action, we can picture the level of comfort they have when thinking about cooperative entrepreneurship. The higher the number of support initiatives young Romanian people are invoking for cooperative entrepreneurship, the lower their level of comfort with the position of cooperative entrepreneur is.

For addressing the affective stage, we have formulated a question that is focused on the support that young people envisage they need to initiate a cooperative or a classic business (Figure no. 2). This support is translated into punctual actions that the respondents would feel necessary to help them launch into cooperative and/or classic entrepreneurship. The respondents have multiple choices for answering. 
They could choose several actions as being necessary to initiate a cooperative, others for initiating a classic business, or they could mark both options or none of them.

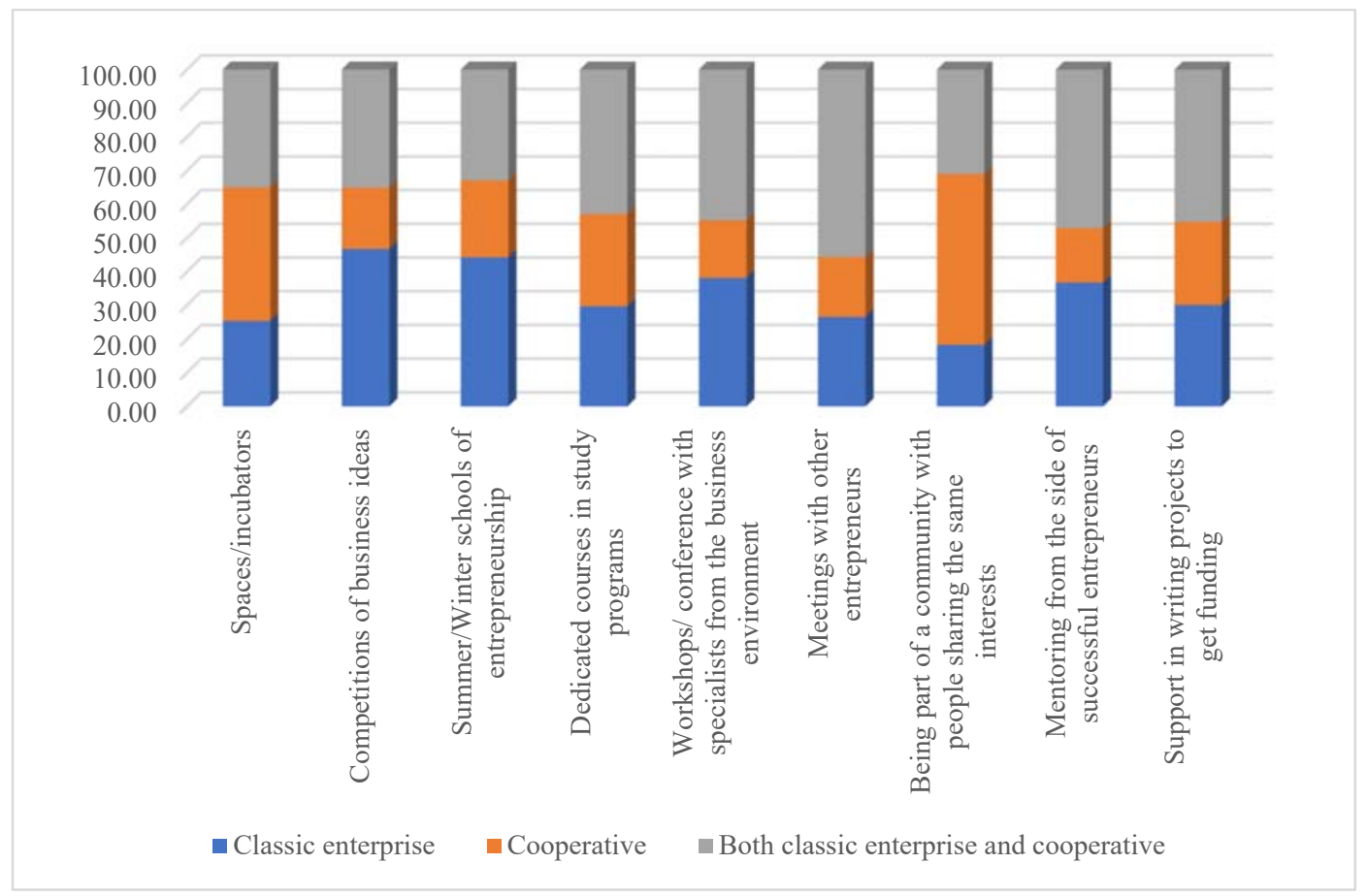

Figure no. 2. Respondents' perspectives on the support they need to initiate a classic enterprise, a cooperative, or both of them

As shown in figure no. 2, young Romanian people are feeling comfortable with the cooperative option when initiating a business, as only two support actions out of nine register a predominant percentage associated with cooperative entrepreneurship. Two of the most relevant activities that respondents find useful for initiating a cooperative are represented by the existence of spaces/incubators where the potential entrepreneurs could interact and gain confidence in this kind of governance; and the involvement into a community where people are sharing similar interests. These two activities are interconnected, namely a community could have a high potential in developing its activities into spaces/incubators or vice versa, the spaces such as incubators could generate the creation of a community focused on cooperatives. For sure, these two components are constituting a necessity for the young people that would like to feel more comfortable with the cooperative option when initiating a business.

Among the actions that the respondents find most necessary in order to support both the classic and the cooperative entrepreneurship are the "meetings with other entrepreneurs" and "mentoring from the side of successful entrepreneurs". The two aforementioned actions are highly connected by putting a particular focus on the support that potential young entrepreneurs need from the side of more experimented entrepreneurs.

The balance between the support actions that respondents find necessary to put into practice a classic enterprise and a cooperative is equilibrated. This result may indicate that young Romanian people feel a similar level of comfort when initiating a cooperative as in the case of a classic business. This is also in line with the findings of Dabija and Băbuț (2019). The difference that is made in the vision of respondents between initiating a classic business or a cooperative refers to the particularity of needed actions: for the classic enterprise, competitions of business ideas, and the organization of summer/winter schools of entrepreneurship are prioritized, while in the case of cooperatives, joining a community and a space/incubator are essential. We may conclude that young Romania people have a 
similar openness towards cooperative entrepreneurship as for a classic enterprise, only that different support actions are required.

\section{Conative element in relation to cooperative entrepreneurship}

By passing to the conative stage of the marketing, we are addressing a question that surprises the respondents' preference for a particular role within the cooperative. Addressing this question allows us to see the way young Romanian people are willing to connect with cooperative entrepreneurship by attributing themselves to a more active or passive role in relation to a cooperative. Practically, the respondents have to project themselves into the role of an entrepreneur, member, and client and express their level of agreement on a Likert scale, from 1 (strongly disagree) to 7 (strongly agree) for each of them.

The intentions of the respondents in relation to these various roles are exposed below (Figure no. 3).

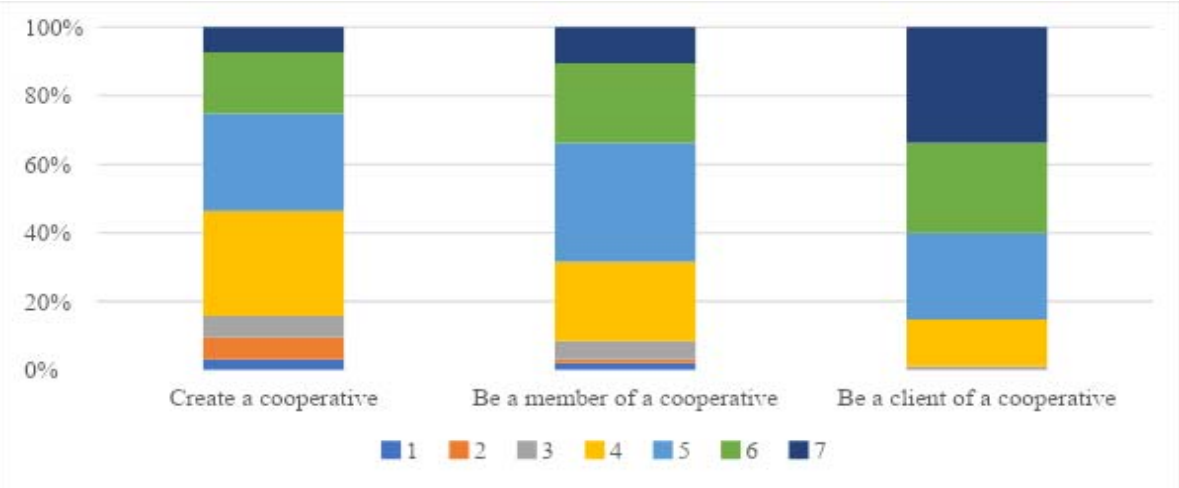

Figure no. 3. The respondents' intentions in relation to cooperatives

For the role of cooperative entrepreneur, the highest percentage $(31 \%)$ of the respondents are manifesting a neutral attitude, followed by the "partially agreement" option that registered $28.4 \%$ of the answers. In the case of being a member of a cooperative, the highest percentage (35\%) was associated with "the partially agreement" option, followed by the "neutral" and "moderately agreement" variants that have similar shares of $23.16 \%$. When approaching the role, the respondents are moderately agreeing to be clients of a cooperative (median 6), and the higher percentage of $34 \%$ of the respondents are strongly agreeing being clients of a cooperative. Concluding, the respondents are showing a larger interest in supporting the cooperatives as clients, and even as members, and less being initiators of a cooperative.

\section{Conclusions}

Approaching entrepreneurship in connection to cooperative is a relatively new subject into the scientific literature. Moreover, our paper proves its originality by addressing the subject of cooperatives into a country that has a controversial history in relation to the subject. The main contribution of our paper consists in picturing the attitude of young Romanian people on the subject of cooperative entrepreneurship. The attitude is studied through its cognitive, affective and conative components that are captured through a questionnaire applied to the target group. The results of our paper indicate that even though young Romanian people have a fragile knowledge about cooperatives, they are not rejecting the possibility of creating a cooperative as long as they could find support into a community where people are sharing similar interests. Another encouraging result shows us that the respondents are feeling comfortable about initiating a cooperative as much as a classic business.

Our work is useful for the representatives of the cooperatives that could do more efforts towards increasing the popularity of their businesses among the young Romanian people that have almost no knowledge regarding the cooperative brands. Moreover, the authorities could be encouraged by the 
positive feelings and intentions of the respondents towards cooperatives, and develop schemes, responsive policies and programmes that could support and promote the cooperative business model. In addition, various actors of the society could develop together solutions for covering the need of dedicated spaces and communities expressed by young Romanian respondents to encourage cooperative entrepreneurship.

Our research has its limits represented by the narrow number of received responses, but an extension of the study, even by surprising the attitude towards cooperative entrepreneurship into another country, is envisaged.

\section{References}

Barin Cruz, L., Alves, M.A. and Delbridge, R., 2017. Next steps in organizing alternatives to capitalism: toward a relational research agenda. Management, 20, pp.322-335.

Bastida, M., Pinto, L.H., Blanco, A.O. and Cancelo, M., 2020. Female Entrepreneurship: Can Cooperatives Contribute to Overcoming the Gender Gap? A Spanish First Step to Equality. Sustainability, 12(6), pp. 1-17.

Chhabra, M., 2021. Understanding marketing multi attribute model simplified, [online] Available at: $<$ https://hevodata.com/learn/marketing-multi-attribute-model/ > [Accessed 21 March 2021].

Dabija, D.C. and Băbuț, R., 2019. Enhancing Apparel Store Patronage through Retailers' Attributes and Sustainability. A Generational Approach. Sustainability, 11(17), 4532.

ICA (International Cooperative Alliance), n.d. Cooperative identity, values and principles, [online] Available at: <https:/www.ica.coop/en/cooperatives/cooperative-identity\#cooperative-principles> [Accessed 15 March 2021].

Iosif, A.E., Capelli, S. and Sîrbu, M.O., 2020. Is There Any More Space for the Cooperatives Into the Romanian Market? In: R. Pamfilie, V. Dinu, L. Tăchiciu, D. Pleșea, C. Vasiliu eds. 6th BASIQ International Conference on New Trends in Sustainable Business and Consumption. Messina, Italy, 4-6 June 2020. Bucharest: ASE, pp.1187-1195.

Jain, V., 2014. 3D model of attitude. International Journal of Advanced Research in Management and Social Sciences, 3(3), pp. 1-12.

Petrescu, C., 2011. Cooperaţia în România-actor al economiei sociale [The cooperative in Romaniaactor of the social economy]. Calitatea vieţii, 4, pp.409-430.

Roman, M. and Paraschiv, D.M., 2019. The Young Entrepreneurs of Europe and the Role of International Mobility. Amfiteatru Economic, 21(Special No. 13), pp.763-777.

Ţigu, G., Iorgulescu, M.C., Răvar, A.S. and Lile, R., 2014. A Pilot Profile of the Social Entrepreneur in the Constantly Changing Romanian Economy. Amfiteatru Economic, 17(38), pp.25-43. 